\title{
Epiregulin as a marker for the initial steps of ovarian cancer development
}

\author{
ABRAHAM AMSTERDAM ${ }^{1}$, ELIAS SHEZEN $^{2}$, CALANIT RAANAN $^{3}$, YASMIN SLILAT $^{1}$, \\ ALON BEN-ARIE $^{4}$, DIANA PRUS ${ }^{5}$ and LETIZIA SCHREIBER ${ }^{6}$ \\ Departments of ${ }^{1}$ Molecular Cell Biology, ${ }^{2}$ Immunology and ${ }^{3}$ Biological Services, The Weizmann Institute of Science; \\ ${ }^{4}$ Kaplan Medical Center, Rehovot 76100; ${ }^{5}$ Department of Pathology, University Hospital, \\ Hadassah Ein Kerem, Jerusalem 911210; ${ }^{6}$ Wolfson Hospital, Holon 58100, Israel
}

Received May 30, 2011; Accepted June 20, 2011

DOI: $10.3892 /$ ijo.2011.1123

\begin{abstract}
Epiregulin (Ep) was found to be produced in noncancer ovarian cells in response to gonadotropin stimulation as well in ovarian cancer cells in an autonomous manner. However, there were no systematic follow-up studies of Ep expression in the development of different stages of ovarian cancer. Using specific antibodies to Ep and the indirect immunocytochemistry methods, we found that in normal ovary the staining for Ep was mainly confined to the epithelial cells, while the stromal cells were only occasionally and moderately stained. In contrast in benign serous and mucinous tumors most of the tumor cells showed a clear staining in the cytoplasm. In borderline serous and mucinous tumors the staining was much more intensive, and appear occasionally in aggregated form. In serous, mucinous and endometrioid carcinomas labeling remain high, with more frequent aggregated form. It is suggested that follow-up of the expression of Ep can serve as a reliable early indication of the development of ovarian cancer. Moreover, the cytoplasmic aggregation of Ep may suggest a specific mechanism of the release of this growth factor to the extracellular space in order to exert its autocrine and paracrine effect on the family of the EGF receptors.
\end{abstract}

\section{Introduction}

Ovarian cancer is the most lethal gynecological cancer in women because early detection is extremely difficult (1-14) and because it is resistant to most chemotherapic drugs (15-17). The average lifespan after detection is 40.8 months for serous cancer, 21.3 months for clear cell carcinomas, 17.6 months for mucinous carcinomas and 50.9 months for endometrioid ovarian carcinomas (11). Amphiregulim (Ar) and Ep, being EGF-like family members, confer binding specificity also for the ERBB

Correspondence to: Dr Abraham Amsterdam, Department of Molecular Cell Biology, The Weizmann Institute of Science, Rehovot 76100, Israel

E-mail: abraham.amsterdam@weizmann.ac.il

Key words: ovarian cancer, p53, EGF-like factors, epidermal growth factor receptor
4 receptors $(18,19)$. Ar and its receptor, epidermal growth factor receptor (EGFR), were expressed in a series of invasive ductal breast carcinoma specimens (20). Ep was found to be involved in the stimulation of tyrosine phosphorylation of ERBB-4 and EGFR in human breast carcinoma cell lines (21).

Ep exerts a mitotic activity in various primary cell types, such as rat hepatocytes (22), as well as in various types of human cancer cell lines, especially in epithelial tumor cell lines (22). In 1991 Johnson et al (23) demonstrated expression of Ar in ovarian carcinoma, and the localization of endogenous $\mathrm{Ar}$ in the nucleus. Immunohistochemical detection of EGF gene family was also demonstrated in ovarian carcinogenesis. In 1995 Gordon et al (25) demonstrated mRNA phenotyping of the major ligands and receptors of EGF gene family in human epithelial cancer cell lines. It was demonstrated that knockout of heparin-binding EGF-like growth factor can be a potential method to attenuate cancer progression (reviewed in refs. 26,27 ).

Transforming growth factor $\alpha$, Ar and crypto- 1 are frequently expressed in advanced human ovarian carcinoma (28). Expression of epidermal growth factors was demonstrated in endometrial cancer (29). Recently, an association of Ep expression in tumorigenesis through activation of Ki-Rassignalling pathway has been suggested in human colon cancer cells (30). Likewise, Ep was found to be upregulated and stimulated growth of human pancreatic cancer cells (31).

Ep and Ar were found to be expressed in the normal ovary during the cycle $(32,33)$. These growth factors bind to EGFR, ERBB2 or ERBB4 receptors leading to phosphorylation of the receptor $(34,35)$ and activation of ERK $1 / 2$ by the dual phosphorylation calalysed by MAPKK and MAPKKK (36-40). This MAPK cascade, which is one of the major intracellular signaling pathways, plays a key role in proliferation, differentiation and apoptosis (36-40). In quiescent cells, MEK acts as a cytoplasmic anchor of ERK 1/2, and when activated by stimulation, ERK $1 / 2$ is phosphorylated on the threonine and tyrosine residues, which is then dissociated from MEK. This dissociation is necessary for nuclear translocation of ERK 1/2 (36-40). Upon stimulation, the nuclear localization of pERK $1 / 2$ is required, for example for changes in neurite outgrowth in PC12 cells, and the transformation of fibroblasts (reviewed in refs. 41,42). 


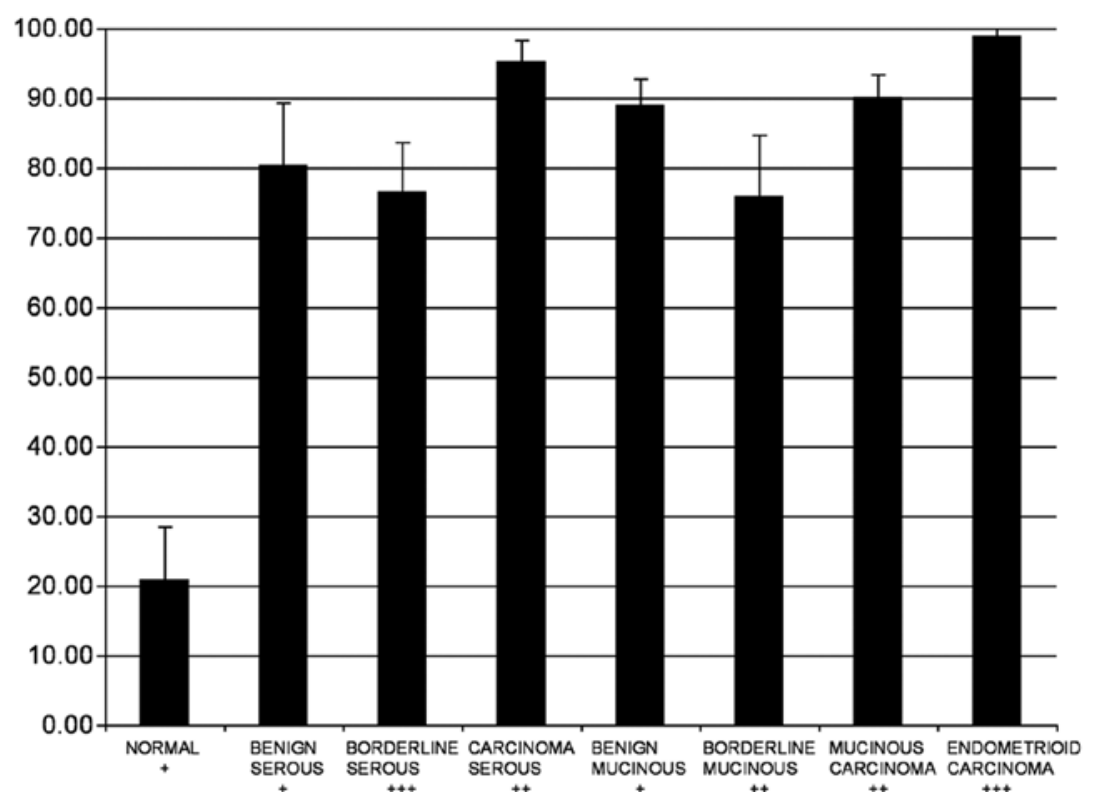

Figure 1. Percentage of labeled cells with antibodies to Ep at different stages of tumor development and carcinogenesis (stage II) of serous, mucinous and endometrioid cancer. The difference between normal ovary, benign serous borderline tumors as well as carcinomas is significant $(\mathrm{p}<0.000013)$. The differences between normal ovaries, mucinous tumors and carcinomas is highly significant $(\mathrm{p}<0.0001)$, as well as for endometrioid carcinomas compared to normal ovary $(\mathrm{p}<0.000004) .+$, intensity of labeling.

There have been many attempts to cure ovarian cancer with poor success, using antibodies to EGFR. However, recently monoclonal antibodies cetuximab and panitumub have established efficacy as single agent and in combination with chemotherapy in advanced colorectal cancer and lung carcinomas $(43,44)$. In addition, high mRNA levels of EGF ligands; Ep and Ar have been associated with increased responsiveness to cetuximab (reviewed in ref. 45).

Recently, genetic and pharmacological analysis identified a set of genes such as EGFR ligand Ep, cyclosyngenase-2 (COX2 and the metalloproteinase- 1 and -2 , that have been found to be associated with metastasis in a variety of cancers (46). It was, therefore, suggested that inhibition of EGFR and COX2 could minimize the development and metastasis of these cancers (46).

As for the ovarian cancer, there is no follow-up of the appearance of Ep, and the progression of tumor development, although it is evident that ovarian cancer cells produce EGF-like factors (reviewed in ref. 47). In the present work, we demonstrate that the high levels of Ep is already evident in benign tumors and borderline tumors. The early detection of this growth factor can greatly assist in selecting the proper therapy as early as possible. Thus, the lifespan of women suffering from ovarian cancer, that is presently considered as a lethal disease, could be improved.

\section{Materials and methods}

Materials. Monoclonal antibodies to p53 (clone 421) were kindly donated by Professor M. Oren of our Institute. Antibodies to epiregulin were goat anti-human epiregulin affinity purified, R\&D Systems. Second specific antibodies conjugated to HRP were from N-Histofine, Japan.

Procedures. Localization of Ep was performed by the indirect immunostaining method of ovarian sections, formaldehydefixed, and paraffin-embedded specimens $(3,48-50)$, obtained from women at the age of 41-79, through several hospitals in Israel. For control, sections of normal ovaries were obtained from women aged of 41-73. Specimens of paraffin sections were obtained from 11 normal ovaries and 8-11 ovaries of benign, borderline and carcinomas of each group. As for endometrioid cancer, we obtained only 2 carcinoma specimens. All carcinomas were at stage II. Permissions for the research were obtained from Helsinki Committees of each hospital: Kaplan Medical Center, Rehovot, Israel, Hadassah University Hospital, Ein Kerem Jerusalem, Israel, and the Wolfson Hospital, Holon, Israel. Staining of sections with anti-p53 were performed using specific antibodies, followed by staining with secondary specific antibodies conjugated to HRP against the primary antibodies.

Microscopic examination. Immunostained sections and parallel sections stained with hematoxylin and eosin were observed in Lietze or Nikon microscopes, using x10-x1000 magnification. For scoring the number of labeled cells and nuclei in normal and different stages of the ovarian tumor development, pictures were taken at magnification x1000. Eight to twelve different areas of stained slides of each different stage of ovarian tumor development (and controls of normal ovaries) were photographed and the number of labeled nuclei and total nuclei were scored, calculating the percentage of labeled nuclei in each photograph, and the mean value $\pm \mathrm{SD}$ of all fields were calculated. At each stage of the ovarian tumors development (and normal tissue) total of 950 nuclei were scored.

Statistical analyses. Statistical evaluation of the different percent of labeled nuclei among the different stages of ovarian tumor development was performed, including control of normal ovary. Analysis of variance (ANOVA) followed by multiple comparison tests or Student's t-test as appropriate was performed.Calculations were performed using SPSS software (Student's t-test, Version II, Chicago IL, USA). Values of $\mathrm{p}<0.05$ were considered statistically significant. 

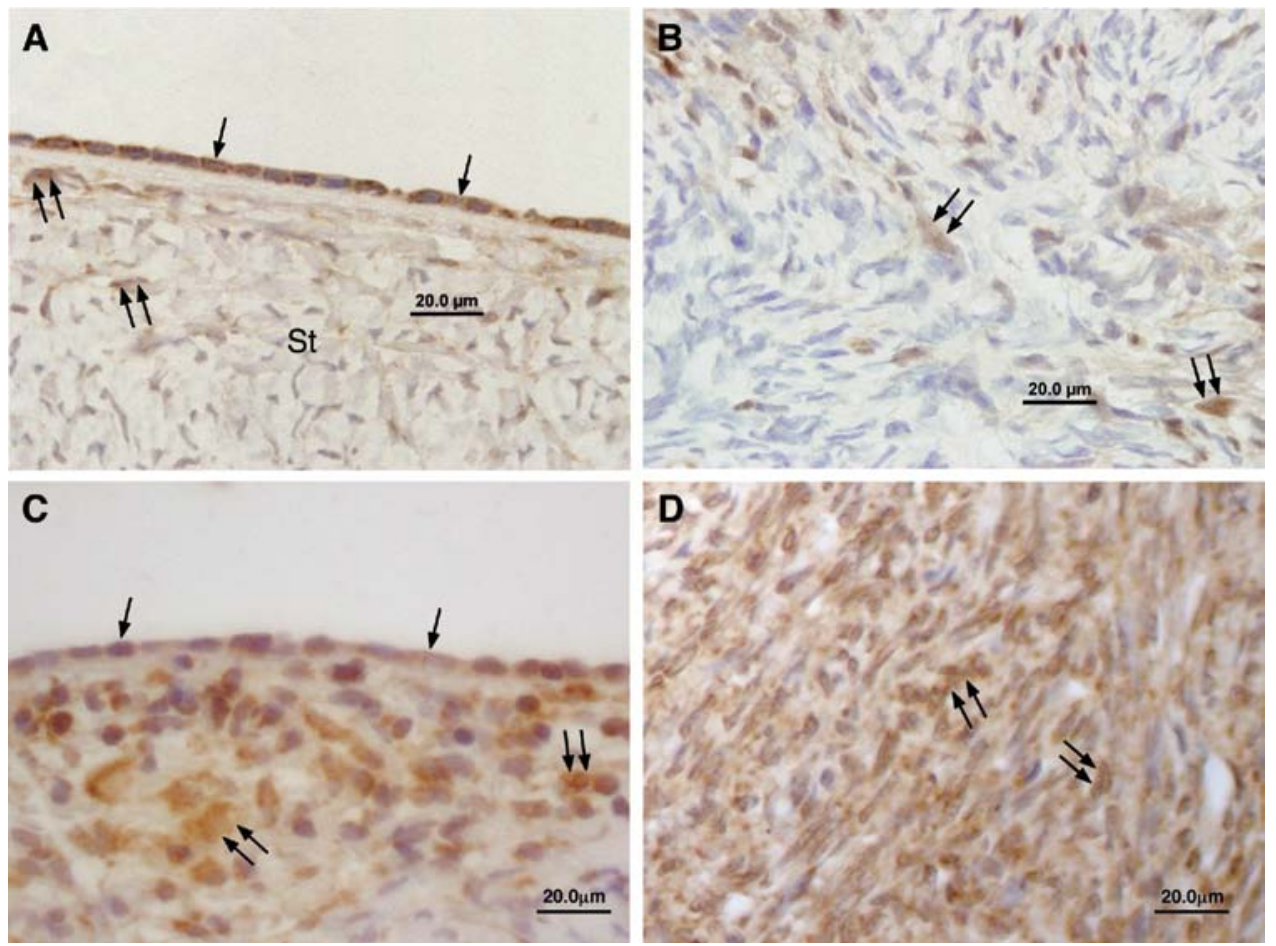

Figure 2. Intensity of staining normal ovary. (A) The layer of epithelial cells is clearly labeled with antibodies to Ep (arrows). Some labeling is evident occasionally in stromal cell (double arrows). (B) Labeling is also evident only occasionally in the bulk of the stromal cells (double arrows). (C) Another normal ovary (according to the classification using straight morphology). The epithelial layer is clearly labeled, with antibodies to Ep (arrows). Stromal cells are also clearly and densely labeled (double arrows). (D) The labeling is intense also in the bulk of the stromal cells (double arrows). It is therefore suggested to be considered of high potential to develop a tumor and was not scored as normal ovary in our statistic evaluation of staining. Original magnification x1000.
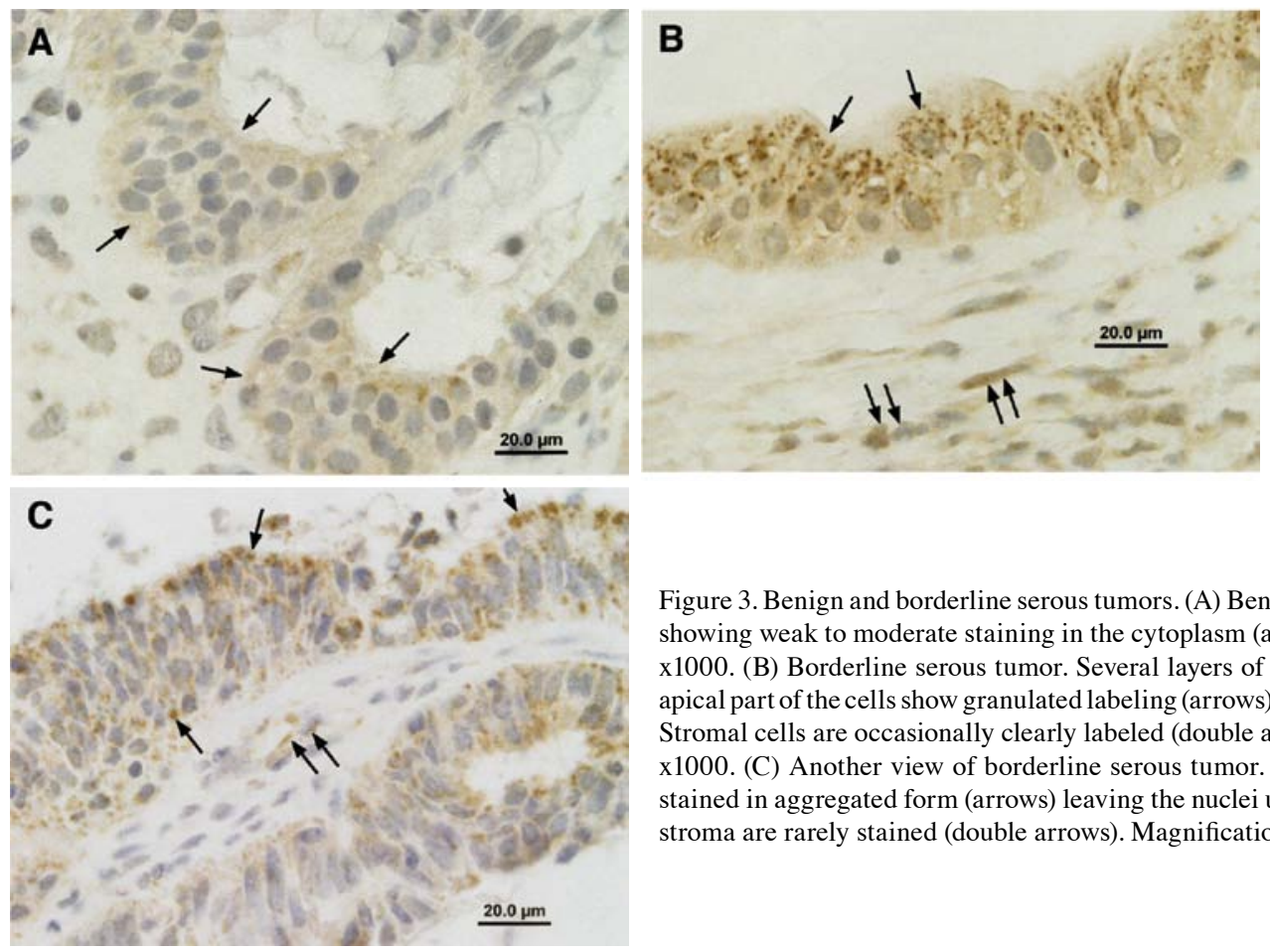

Figure 3. Benign and borderline serous tumors. (A) Benign serous tumor cells showing weak to moderate staining in the cytoplasm (arrows). Magnification x1000. (B) Borderline serous tumor. Several layers of cells are labeled. The apical part of the cells show granulated labeling (arrows) with antibodies to Ep. Stromal cells are occasionally clearly labeled (double arrows). Magnification $\mathrm{x} 1000$. (C) Another view of borderline serous tumor. Cytoplasm of cells is stained in aggregated form (arrows) leaving the nuclei unstained. Cells of the stroma are rarely stained (double arrows). Magnification x 1000 .

\section{Results}

In order to verify whether Ep can serve as an early marker for the development of ovarian cancer, the following steps were taken.

Selection of antibodies. We have selected the R\&D antibodies for the staining of Ep since, among six companies this was the

only antibody that could be blocked by pre-incubation with x20 concentration in molar ratio of Ep prior to the staining of the sections (data not shown).

Normal ovary. We have analyzed specimens of normal ovary, characterized by straight morphology, following H\&E staining and staining with antibodies to EP, and found that the labeling (Figs. 1 and 2A) with Ep antibodies was confined mainly to the 

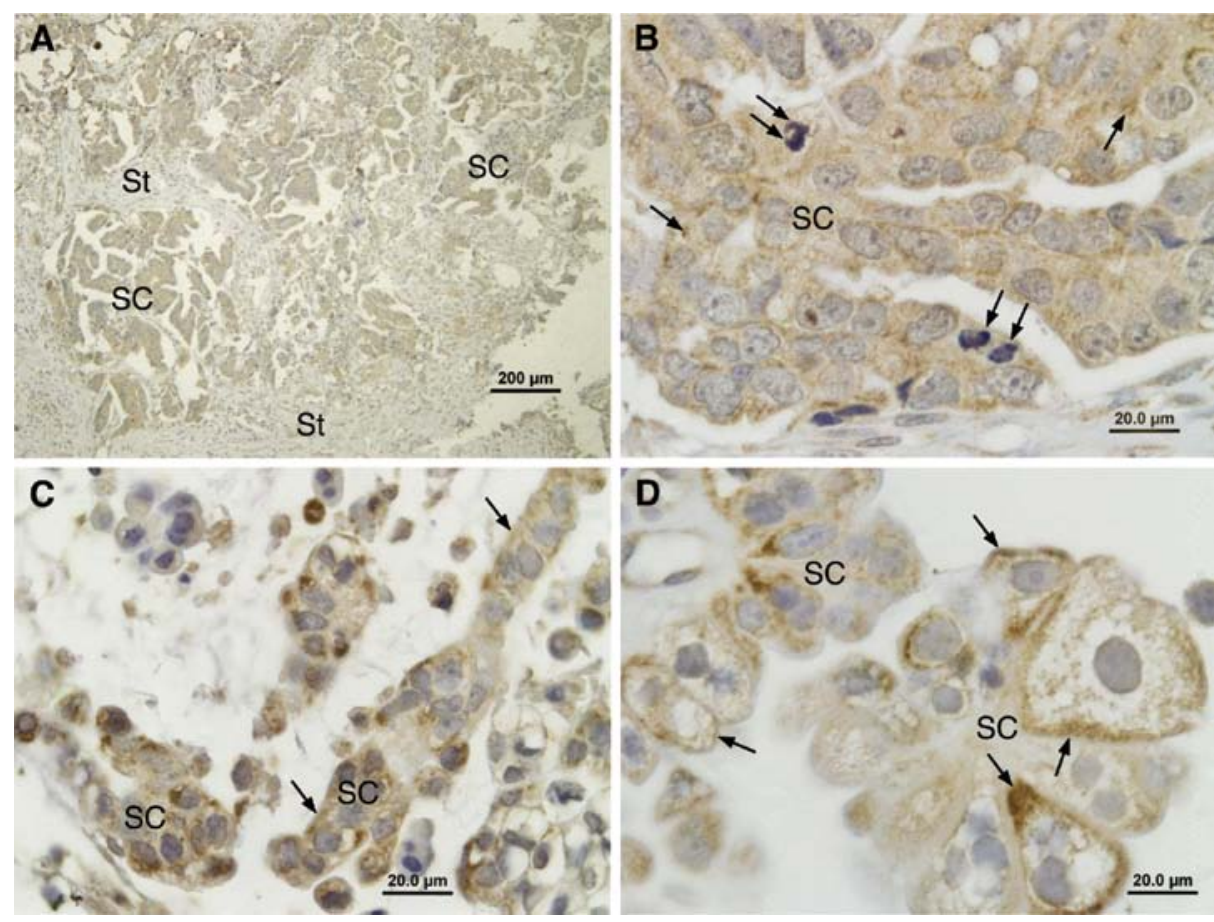

Figure 4. Serous carcinoma. (A) Low magnification. Islet of clusteral carcinoma cells are clearly labeled with antibodies to Ep (SC). Stromal cells are faintly stained (St). (B) Serous carcinoma cells at high magnification (SC). Cytoplasm of cells is clearly stained occasionally in aggregates (arrows), leaving the nuclei unstained. Mitotic figures are evident. Cells in metaphase and anaphase are visible (double arrows). Magnification x1000. (C) A different view of serous carcinoma (SC). Cytoplasm of carcinoma cells is more homogeneously stained than in B (arrows). Magnification x1000. (D) Another different view of serous carcinoma (SC). Nuclei and cell bodies are much larger. Staining is confined to the circumference of cells (arrows). Magnification x1000.
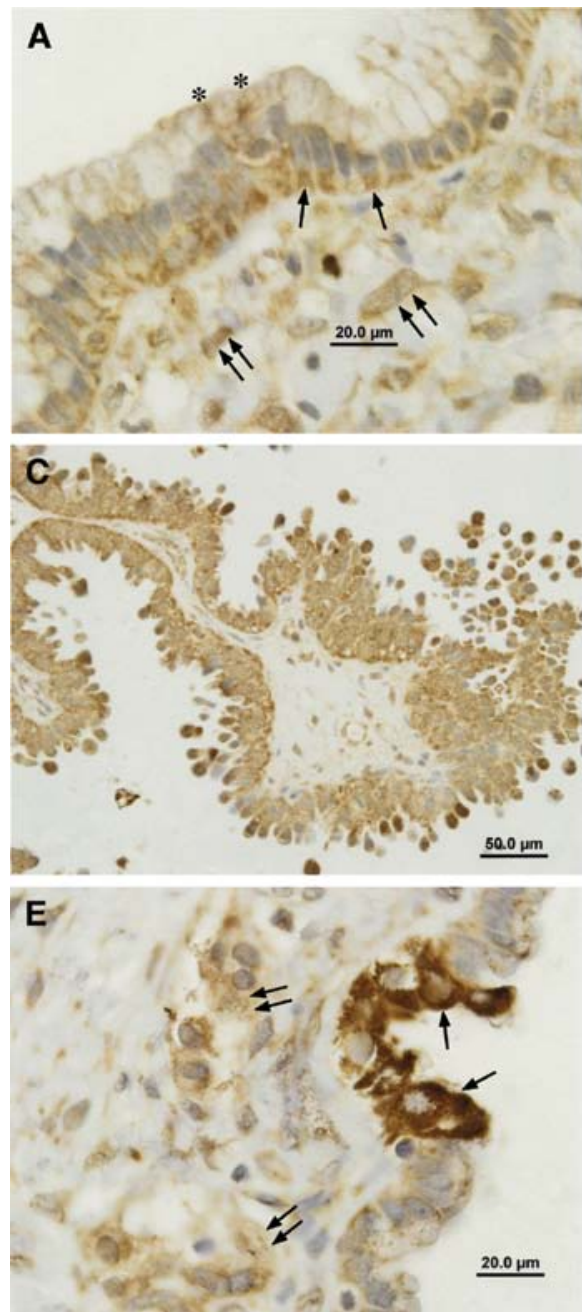

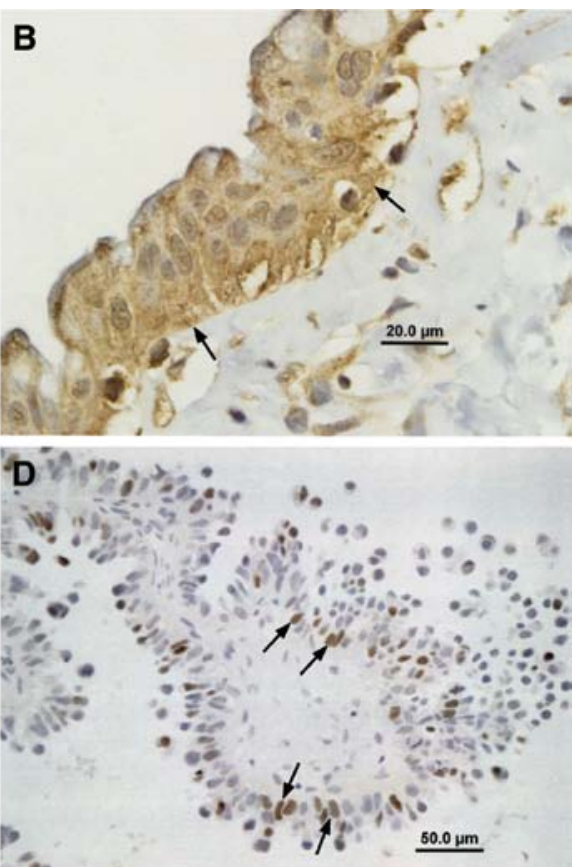

Figure 5. Mucinous tumors. (A) A layer of benign tumor elongated cells. Staining for Ep is evident in the basal part of the cells (arrows) leaving the main body of the cells unstained. Some labeling is also evident at the upper part of the cells (asterisks). Stromal cells are also clearly stained (double arrows). Magnification x1000. (B) A different view of a benign mucinous tumor. Tumor cell cytoplasm is more homogeneous stained with Ep antibodies (arrows) $\mathrm{x} 1000$. (C and D) Parallel sections stained with anti-Ep and anti-p53 antibodies respectively, showing borderline mucinous tumor. Staining of all tumor cells with antibodies to Ep is clearly evident in (C), while part of the cell nuclei are clearly stained with anti-p53 antibodies in (D) (arrows). Original magnification x400. (E) A different pattern of staining of a borderline mucinous tumor. Clusters of tumor cells are heavily stained with antibodies to Ep (arrows) while the neighboring stromal cells are clearly stained as well (double arrows). Magnification x1000. 

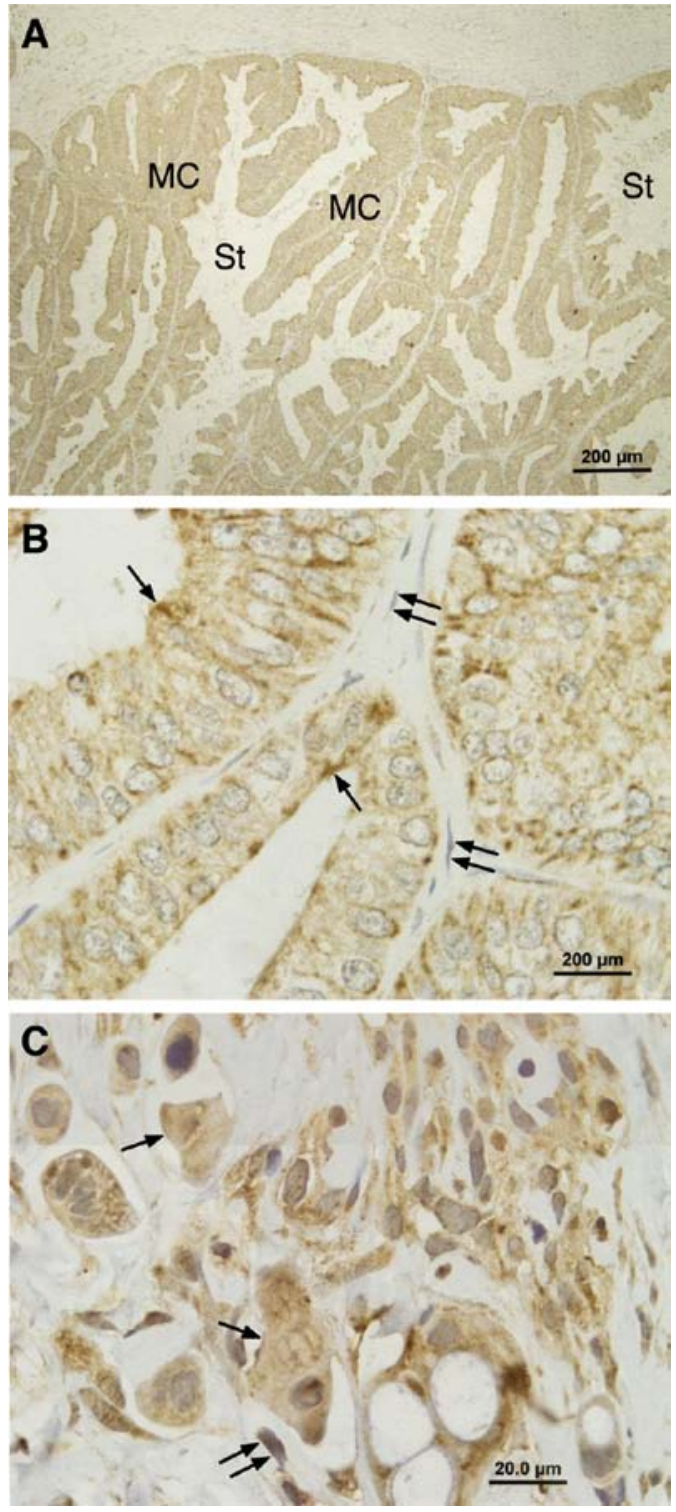

Figure 6. Mucinous carcinomas. (A) At low magnification carcinoma cells, organized in a specific patter, are clearly labeled with antibodies to Ep (MC). Stromal cells are only weakly labeled (St). Magnification x100. (B) At high magnification cancer cells are organized in a specific array. Cells are clearly labeled with aggregates of Ep, mainly at the circumference of the cells (arrows) Stroma cells remained essentially unstained (double arrows). Magnification x1000. (C) Different appearance of mucinous carcinoma cells. Cancer cells are less organized than in (B) and the labeling with antibodies to Ep is more homogeneous (arrows). Magnification x1000.

epithelial cells, while stromal cells were labeled only occasionally (Fig. 2). However, closer to $50 \%$ of the normal ovary specimens (5 of 11) were widely and clearly stained with Epi antibodies (Fig. 4C and D), suggesting that Ep staining could be a good indication for initiation of tumor growth that cannot be observed by straight morphology, or using some other biomarkers. These ovaries were not scored as normal ovaries.

Serous being tumors. Percentage of labeled cells increased dramatically (Figs. 1 and 3A). A weak but clear staining was evident in all layers of the tumor cells.

Serous borderline tumors. In borderline serous tumors there were two types of staining. The first type of staining with anti-
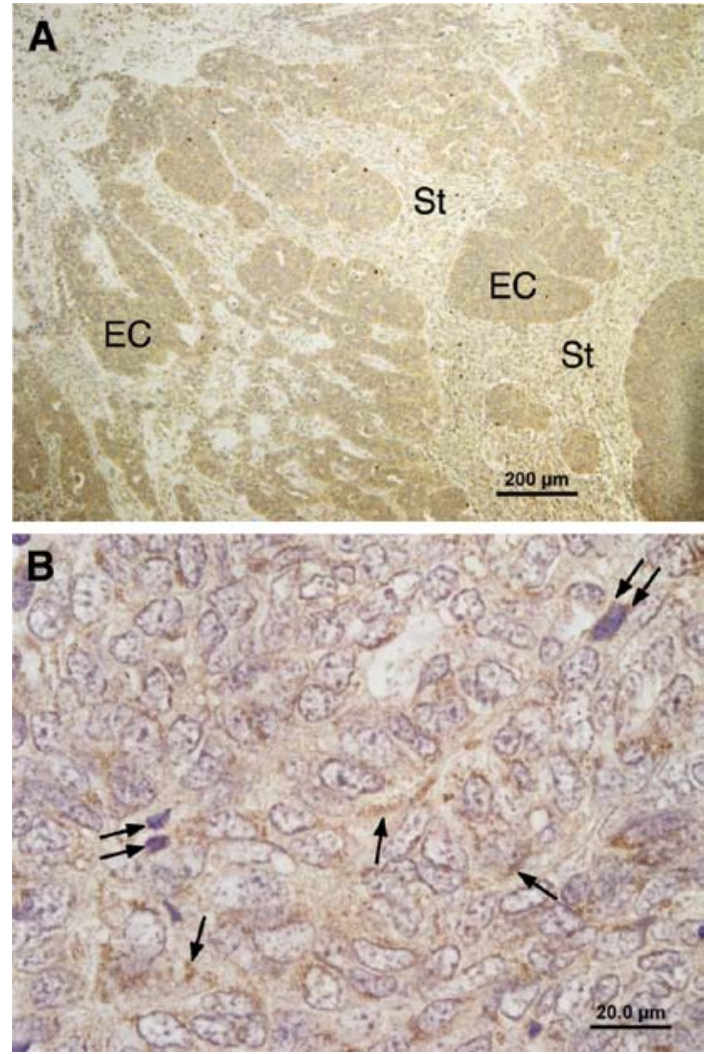

Figure 7. Endometrioid carcinoma. (A) Aggregated cancer cells are embedded in stromal cells, clearly labeled with antibodies to Ep (EC). Stromal cells are only weakly labeled (St). (B) High magnification of endometrioid cancer cells. Cells are tightly packed. Ep appears in aggregates (arrows). Mitotic images are evident (double arrows). Magnification x1000.

bodies to Ep revealed weak but clear staining in cells bordering the ovarian stroma (Fig. 3B), while the apical part of the cells was stained with distinct small aggregates. Some of the stromal cells were clearly labeled with Ep antibodies. In the other view of borderline tumors the tumor cell nuclei were smaller and Ep aggregates were present both in the apical and the basal part of the cells (Fig. 3C). Only few stromal cells were stained with anti-Ep antibodies.

Serous ovarian carcinoma. In serous ovarian carcinomas (stage II) islands of tumor cell aggregates were clearly evident, embedded in the ovarian stromal tissue. They were clearly stained with antibodies to Ep, while the stromal tissue remained essentially unstained (Fig. 4A). At high magnification, serous carcinomas have sometimes different appearance: the first one showed large nuclei and clear cytoplasmic staining with Ep antibodies, leaving the nuclei unstained. Only mild staining could be observed in the cytoplasm. Occasionally aggregates of stained Ep were also evident (Fig. 4B). In the second appearance of serous carcinoma the cytoplasmic staining of Ep was more intensive and more homogeneous (Fig. 4C). The third appearance was characterized by large cells with labeling mainly at the circumference of the cells leaving the nuclei unstained (Fig. 4D).

Mucinous bening tumors. Bening tumors showed two difference appearances. The first one showed labeling with anti-Ep antibodies at the basal part of the cells and some in the apical part, leaving the rest of the cell body, including the nuclei, 
unstained (Fig. 5A). Stromal cell adjacent to the tumor cells were moderately labeled with Ep antibodies. In the second appearance the entire cytoplasm of tumor cells was clearly labeled with Ep antibodies (Fig. 5B), while some stromal cells were also labeled.

Mucinous borderline tumors. In order to verify whether borderline tumors contain already muted p53, we stained adjacent sections one with Ep antibodies (Fig. 5C) and the second with anti-p53 antibodies (Fig. 5D). Distinct staining to p53 was evident in part of the cell nuclei indicating that mutation of p53 is already evident in borderline mucinous tumors. Additional image of borderline tumor was evident with clusters of cells heavily labeled with anti-Ep antibodies (Fig. 5E). Interestingly, prior to staining the specific tumor was classified according to the morphological appearance, at the most, as a benign tumor.

Mucinous carcinomas. At low magnification mucinous carcinoma show more differentiated image than serous carcinomas and was clearly stained with Ep antibodies (Fig. 6A). At high magnification, two distinct patterns of staining were revealed: the first was with an organized form. Clear labeling was mainly confined to the edges of the tumor cells (Fig. 6B). Stromal cells were essentially free of labeling. In the other image, cells were bigger and the entire cytoplasm was stained. Occasionally large cytoplasmic vacuoles were evident. Stromal cells were often stained in the cytoplasm leaving the nuclei unstained (Fig. 6C).

Endometrioid ovarian tumors. We obtained only two specimens of ovarian endometrial carcinomas (stage II). Low magnification showed bulks of tumor cells stained with anti-Ep antibodies. Stromal cells were weakly stained and most of them remained unstained (Fig. 7A). High magnification revealed dense appearance of cancer cells with mitotic figures. Staining with Ep antibodies mainly appeared in aggregates. Nuclei were free of labeling (Fig. 7B).

\section{Discussion}

In the present report we clearly demonstrate that Ep can serve as a sensitive early marker for ovarian tumor development and carcinogenesis. It was earlier demonstrated by RT-PCR that there was no difference in the content of RNA between normal ovary and cancer ovary (51). However, there is no documentation on the protein level that could be affected by siRNA and possibly by various intracellular proteinases (reviewed in refs. 52-54). Moreover, high percentage of normal ovaries defined by straight morphology were found by us as already at the stage of benign or even borderline tumors. In addition, analysis of RNA on to the entire cancer tissue may not be always accurate since it may also contain residues of non-cancer tissue. Therefore, the protein levels as estimated by immunocytochemistry may be more accurate as for the level of Ep in the different stages of tumor and malignant cancer development. We found a similar situation for phosphorylated ERK $1 / 2$ which is the outcome of activation of EGF receptor, which in turn will phosphorylate MAPK and activate the ERK $1 / 2(55)$.

Serous carcinomas include $80 \%$ of ovarian cancer (3) while mucinous carcinomas traditionally represent $12-13 \%$ of ovarian carcinomas. However, recently, according to a variety of biomarkers it was suggested to represent only 2-3\% of total carcinomas (16). Nevertheless the different images that appeared following staining with antibodies to Ep would suggest novel subtypes of ovarian carcinomas. We estimate the amounts of Ep by the intensity of staining with anti-Ep antibodies. We avoid performing Western blot analyses since at benign, borderline tumors and carcinomas stage 2 most probably the tissues contained a significant amount of stromal cells which may blur the results. It should be noted that other members of the EGF-like member proteins such as HB-EGF and Ar may also serve as sensitive members for the development of benign, borderline and ovarian cancer as exemplified in the present work for Ep.

High magnification images revealed in the present report that Ep was often found in cytoplasmic aggregates very often at the circumference of the cells. This may suggest a specific mechanism of release (56) or shedding (57) of the growth factor without loosing other essential intracellular organelles. This issue could probably be solved using high resolution EM where Ep is stained with Ep antibodies attached to colloidal gold particles, which produce a high contrast in the electron beam of the microscope (reviewed in ref. 58). It should be noted, as mentioned before, that the release of the growth factor to the extracellular space is a prerequisite to exert its mitogenic effect through the activation of MAPK and phosphorylation of ERK 1/2 which will migrate to the nucleus (36-40).

Early detection of ovarian cancer will no doubt improve the prognosis of ovarian cancer and this could be achieved by biomarkers for early detection of the disease as was exemplified in the present report for the EGF-like factor, Ep.

\section{Acknowledgements}

We thank Dr Fortune Kohen of the Department of Biological Regulation at The Weizmann Institute of Science for helpful discussions. We also thank Ms. Danielle Sabah-Israel and Ms. Adi Sela at the Weizmann Institute of Science for typing the manuscript and Ms. Haya Avital from the Photography Section Design, Photography and Printing Branch at the Weizmann Institute of Science. We would also like to thank Ms. Rina Tzoref for helpful editing of this manuscript.

\section{References}

1. Schaner ME, Ross DT, Ciaravino G, Sorlie T, Troyanskaya O, Diehn M, Wang YC, Duran GE, Sikic TL, Caldeira S, Skomedal H, Tu IP, Hernandez-Boussard T, Johnson SW, O'Dwyer PJ, Fero MJ, Kristensen GB, Borresen-Dale AL, Hastie T, Tibshirani R, van de Rijn M, Teng NN, Longacre TA, Botstein D, Brown PO and Sikic BI: Gene expression patterns in ovarian carcinomas. Mol Biol Cell 14: 4376-4386, 2003.

2. Lee H, Park G, Jung JH, Ahn WS, Lee JM, Kim BK and Kang CS: Diagnostic approach using the expression profiling of the P53 tumor suppressor gene and its related proteins in ovarian epithelial tumors. Int J Gynecol Cancer 15: 453-461, 2005.

3. Singer G, Stöhr R, Cope L, Dehari R, Hartmann A, Cao DF, Wang TL, Kurman RJ and Shih IeM: Patterns of p53 mutations separate ovarian serous borderline tumors and low- and highgrade carcinomas and provide support for a new model of ovarian carcinogenesis: a mutational analysis with immunohistochemical correlation. Am J Surg Pathol 29: 218-224, 2005.

4. Bowen NJ, Walker LD, Matyunina LV, Logani S, Totten KA, Benigno BB and McDonald JF: Gene expression profiling supports the hypothesis that human ovarian surface epithelia are multipotent and capable of serving as ovarian cancer initiating cells. BMC Med Genomics 2: 71, 2009. 
5. Vrabie CD, Petrescu A, Waller M and Dina I: Clinical factor and biomarkers in ovarian tumors development. Rom J Morphol Embryol 49: 327-338, 2008.

6. Köbel M, Kalloger SE, Boyd N, McKinney S, Mehl E, Palmer C, Leung S, Bowen NJ, Ionescu DN, Rajput A, Prentice LM, Miller D, Santos J, Swenerton K, Gilks CB and Huntsman D: Ovarian carcinoma subtypes are different diseases: implications for biomarker studies. PLoS Med 5: e232, 2008.

7. Christie M and Oehler MK: Molecular pathology of epithelial ovarian cancer. J Br Menopause Soc 12: 57-63, 2006.

8. Tinelli A, Vergara D, Martignago R, Leo G, Pisanò M and Malvasi A: An outlook on ovarian cancer and borderline ovarian tumors: focus on genomic and proteomic findings. Curr Genomics 10: $240-249,2009$

9. Köbel M, Kalloger SE, Santos JL, Huntsman DG, Gilks CB and Swenerton KD: Tumor type and substage predict survival in stage I and II ovarian carcinoma: insights and implications. Gynecol Oncol 116: 50-56, 2010.

10. Gubbels JA, Claussen N, Kapur AK, Connor JP and Patankar MS The detection, treatment, and biology of epithelial ovarian cancer. J Ovarian Res 3: 8, 2010.

11. Kurman RJ and Shih IeM: The origin and pathogenesis of epithelial ovarian cancer: a proposed unifying theory. Am J Surg Pathol 34: 433-443, 2010.

12. Yurkovetsky Z, Skates S, Lomakin A, Nolen B, Pulsipher T, Modugno F, Marks J, Godwin A, Gorelik E, Jacobs I, Menon U, Lu K, Badgwell D, Bast RC Jr and Lokshin AE: Development of a multimarker assay for early detection of ovarian cancer. J Clin Oncol 28: 2159-2166, 2010.

13. Tuma RS: Origin of ovarian cancer may have implications for screening. J Natl Cancer Inst 102: 11-13, 2010.

14. Pothuri B, Leitao MM, Levine DA, Viale A, Olshen AB, Arroyo C, Bogomolniy F, Olvera N, Lin O, Soslow RA, Robson ME, Offit K, Barakat RR and Boyd J: Genetic analysis of the early natural history of epithelial ovarian carcinoma. PLoS One 5: e10358, 2010.

15. Nakayama N, Nakayama K, Yeasmin S, Ishibashi M, Katagiri A, Iida K, Fukumoto M and Miyazaki K: KRAS or BRAF mutation status is a useful predictor of sensitivity to MEK inhibition in ovarian cancer. Br J Cancer 99: 2020-2028, 2008.

16. García-Sáenz JA, Custodio A, Casado A, Vidart JA, Coronado PJ Martín M, López-Tarruella S, Puente J, Fernández C and Díaz-Rubio E: Platinum-based adjuvant chemotherapy on moderate- and high-risk stage I and II epithelian ovarian cancer patients. Long-term single institution experience and literature review. Clin Transl Oncol 13: 121-132, 2011.

17. Mutsaers AJ, Francia G, Man S, Lee CR, Ebos JM, Wu Y, Witte L, Berry S, Moore M and Kerbel RS: Dose-dependent increases in circulating TGF-alpha and other EGFR ligands act as pharmacodynamic markers for optimal biological dosing of cetuximab and are tumor independent. Clin Cancer Res 15: 2397-2405, 2009.

18. Yarden Y and Sliwkowski MX: Untangling the ErbB signalling network. Nat Rev Mol Cell Biol 2: 127-137, 2001.

19. Holbro T and Hynes NE: ErbB receptors: directing key signaling networks throughout life. Annu Rev Pharmacol Toxicol 44: 195-217, 2004

20. Ma L, De Roquancourt A, Bertheau P, Chevret S, Millot G, SastreGarau X, Espié M, Marty M, Janin A and Calvo F: Expression of amphiregulin and epidermal growth factor receptor in human breast cancer: analysis of autocriny and stromal-epithelial interactions. J Pathol 194: 413-419, 2001.

21. Komurasaki T, Toyoda H, Uchida D and Morimoto S: Epiregulin binds to epidermal growth factor receptor and ErbB-4 and induces tyrosine phosphorylation of epidermal growth factor receptor, ErbB-2, ErbB-3 and ErbB-4. Oncogene 15: 2841-2848, 1997.

22. Toyoda H, Komurasaki T, Uchida D, Takayama Y, Isobe T, Okuyama T and Hanada K: Epiregulin. A novel epidermal growth factor with mitogenic activity for rat primary hepatocytes. J Biol Chem 270: 7495-7500, 1995.

23. Johnson GR, Saeki T, Auersperg N, Gordon AW, Shoyab M, Salomon DS and Stromberg K: Response to and expression of amphiregulin by ovarian carcinoma and normal ovarian surface epithelial cells: nuclear localization of endogenous amphiregulin. Biochem Biophys Res Commun 180: 481-488, 1991.

24. Stromberg K, Johnson GR, O'Connor DM, Sorensen CM Gullick WJ and Kannan B: Frequent immunohistochemical detection of EGF supergene family members in ovarian carcinogenesis. Int J Gynecol Pathol 13: 342-347, 1994.
25. Gordon AW, Pegues JC, Johnson GR, Kannan B, Auersperg N and Stromberg K: mRNA phenotyping of the major ligands and receptors of the EGF supergene family in human ovarian epithelial cells. Cancer Lett 89: 63-71, 1995.

26. Nishi E and Klagsbrun M: Heparin-binding epidermal growth factor-like growth factor (HB-EGF) is a mediator of multiple physiological and pathological pathways. Growth Factors 22: 253-260, 2004

27. Saito M and Kohno K: [Generation of mouse models of human disease using a diphtheria toxin receptor-mediated conditional cell knockout method]. Tanpakushitsu Kakusan Koso 54: 614-620, 2009

28. D'Antonio A, Losito S, Pignata S, Grassi M, Perrone F, De Luca A, Tambaro R, Bianco C, Gullick WJ, Johnson GR, Iaffaioli VR, Salomon DS and Normanno N: Transforming growth factor alpha, amphiregulin and cripto-1 are frequently expressed in advanced human ovarian carcinomas. Int J Oncol 21: 941-948, 2002.

29. Ejskjaer K, Sørensen BS, Poulsen SS, Forman A, Nexø E and Mogensen O: Expression of the epidermal growth factor system in endometrioid endometrial cancer. Gynecol Oncol 104 158-167, 2007.

30. Baba I, Shirasawa S, Iwamoto R, Okumura K, Tsunoda T, Nishioka M,Fukuyama K, Yamamoto K, Mekada E and Sasazuki T: Involvement of deregulated epiregulin expression in tumori-genesis in vivo through activated Ki-Ras signaling pathway in human colon cancer cells. Cancer Res 60: 6886-6889, 2000.

31. Zhu Z, Kleeff J, Friess H, Wang L, Zimmermann A, Yarden Y, Büchler MW and Korc M: Epiregulin is up-regulated in pancreatic cancer and stimulates pancreatic cancer cell growth. Biochem Biophys Res Commun 273: 1019-1024, 2000.

32. Freimann S, Ben-Ami I, Dantes A, Ron-El R and Amsterdam A: EGF-like factor epiregulin and amphiregulin expression is regulated by gonadotropins/cAMP in human ovarian follicular cells. Biochem Biophys Res Commun 324: 829-834, 2004.

33. Ben-Ami I, Freimann S, Armon L, Dantes A, Ron-El R and Amsterdam A: Novel function of ovarian growth factors: combined studies by DNA microarray, biochemical and physiological approaches. Mol Hum Reprod 12: 413-419, 2006.

34. Martínez-Carpio PA, Mur C, Rosel P and Navarro MA: Constitutive and regulated secretion of epidermal growth factor and transforming growth factor-beta1 in MDA-MB-231 breast cancer cell line in 11-day cultures. Cell Signal 11: 753-757, 1999.

35. Schneider MR and Wolf E: The epidermal growth factor receptor ligands at a glance. J Cell Physiol 218: 460-466, 2009.

36. Plotnikov A, Zehorai E, Procaccia S and Seger R: The MAPK cascades: Signaling components, nuclear roles and mechanisms of nuclear translocation. Biochim Biophys Acta Dec 16, 2010. [Epub ahead of print].

37. Keshet $Y$ and Seger R: The MAP kinase signaling cascades: a system of hundreds of components regulates a diverse array of physiological functions. Methods Mol Biol 661: 3-38, 2010.

38. Chuderland D, Konson A and Seger R: Identification and characterization of a general nuclear translocation signal in signaling proteins. Mol Cell 31: 850-861, 2008.

39. Yao Z and Seger R: The ERK signaling cascade - views from different subcellular compartments. Biofactors 35: 407-416, 2009.

40. Jaaro H, Rubinfeld H, Hanoch $T$ and Seger R: Nuclear translocation of mitogen-activated protein kinase kinase (MEK1) in response to mitogenic stimulation. Proc Natl Acad Sci USA 94 3742-3747, 1997.

41. Robinson MJ, Stippec SA, Goldsmith E, White MA and Cobb MH: A constitutively active and nuclear form of the MAP kinase ERK2 is sufficient for neurite outgrowth and cell transformation. Curr Biol 8: 1141-1150, 1998.

42. Vicent S,López-Picazo JM, Toledo G, Lozano MD, Torre W, GarciaCorchón C, Quero C, Soria JC, Martín-Algarra S, Manzano RG and Montuenga LM: ERK1/2 is activated in non-small-cell lung cancer and associated with advanced tumours. Br J Cancer 90: 1047-1052, 2004.

43. Meriggi F, Di Biasi B, Abeni C and Zaniboni A: Anti-EGFR therapy in colorectal cancer: how to choose the right patient. Curr Drug Targets 10: 1033-1040, 2009.

44. Lièvre $A$ and Laurent-Puig P: [Predictive factors of response to anti-EGFR treatments in colorectal cancer] French. Bull Cancer 95: 133-140, 2008

45. Steins MB, Reinmuth N, Bischoff H, Kindermann M and Thomas M: Targeting the epidermal growth factor receptor in non-small cell lung cancer. Onkologie 33: 704-709, 2010. 
46. Eltarhouny SA, Elsawy WH, Radpour R, Hahn S, Holzgreve W and Zhong XY: Genes controlling spread of breast cancer to lung 'gang of 4'. Exp Oncol 30: 91-95, 2008.

47. Miyamoto S, Yagi H, Yotsumoto F, Kawarabayashi $\mathrm{T}$ and Mekada E: Heparin-binding epidermal growth factor-like growth factor as a novel targeting molecule for cancer therapy. Cancer Sci 97: 341-347, 2006.

48. Lee JS, Choi YD, Lee JH, Nam JH, Choi C, Lee MC, Park CS, Juhng SW and Min KW: Expression of cyclooxygenase-2 in epithelial ovarian tumors and its relation to vascular endothelial growth factor and p53 expression. Int J Gynecol Cancer 16 (Suppl. 1): 247-253, 2006.

49. Zeren T, Inan S, Seda Vatansever H, Ekerbicer N and Sayhan S: Significance of tyrosine kinase activity on malign transformation of ovarian tumors: a comparison between EGF-R and TGF-alpha. Acta Histochem 110: 256-263, 2008.

50. O'NeillCJ,Deavers MT,Malpica A, Foster H and McCluggage WG: An immunohistochemical comparison between low-grade and high-grade ovarian serous carcinomas: significantly higher expression of p53, MIB1, BCL2, HER-2/neu, and C-KIT in high-grade neoplasms. Am J Surg Pathol 29:1034-1041, 2005.

51. Tanaka Y, Miyamoto S, Suzuki SO, Oki E, Yagi H, Sonoda K, Yamazaki A, Mizushima H, Maehara Y, Mekada E and Nakano H: Clinical significance of heparin-binding epidermal growth factor-like growth factor and a disintegrin and metalloprotease 17 expression in human ovarian cancer. Clin Cancer Res 11: 4783-4792, 2005.
52. Li C, Feng Y, Coukos G and Zhang L: Therapeutic microRNA strategies in human cancer. AAPS J 11: 747-757, 2009.

53. Amsterdam A, Keren-Tal I, Aharoni D, Dantes A, Land-Bracha A, Rimon E, Sasson R and Hirsh L: Steroidogenesis and apoptosis in the mammalian ovary. Steroids 68: 861-867, 2003.

54. Dahiya N and Morin PJ: MicroRNAs in ovarian carcinomas. Endocr Relat Cancer 17: F77-F89, 2010.

55. Amsterdam A, Shezen E, Raanan C, Schreiber L, Prus D, Slilat Y, Ben-Arie A and Seger R: Nuclear localization of phosphorylated ERK1 and ERK2 as markers for the progression of ovarian cancer. Int J Oncol 39: 649-656, 2011.

56. Sahin U, Weskamp G, Kelly K, Zhou HM, Higashiyama S, Peschon J, Hartmann D, Saftig P and Blobel CP: Distinct roles for ADAM10 and ADAM17 in ectodomain shedding of six EGFR ligands. J Cell Biol 164: 769-779, 2004.

57. Oshima H, Popivanova BK, Oguma K, Kong D, Ishikawa TO and Oshima M: Activation of epidermal growth factor receptor signaling by the prostaglandin E(2) receptor EP4 pathway during gastric tumorigenesis. Cancer Sci 102: 713-719, 2011.

58. Lucocq JM and Gawden-Bone C: Quantitative assessment of specificity in immunoelectron microscopy. J Histochem Cytochem 58: 917-927, 2010. 